\title{
IMPLEMENTASI PENDIDIKAN TOLERANSI \\ DI SEKOLAH: Sebuah Kearifan Lokal \\ di Sekolah Nahdlatul Ulama
}

\author{
Gita Dianita,* Endis Firdaus, dan Saepul Anwar
}

Universitas Pendidikan Indonesia, Bandung

*E-mail: gitadianita95@gmail.com

\begin{abstract}
The research discusses tolerance education through the teaching and learning of Kema'arifan (wisdom) at SMA (Senior High School) Ma'arif Bandung. In contrast to other studies, this research will be more focused on discussing the process of inculcating tolerance values in schools with the background of Nabdatul Ulama (NU). The research will describe how teachers convey tolerance values through classroom teaching and learning. The research employed qualitative method with data collection techniques of interview, observation, and documentary study. The results show that Kema'arifan instruction can provide deeper knowledge about Islam, aswaja, and other groups. In the teaching and learning process, teachers convey the values of tolerance through lecture, and question-answer methods.
\end{abstract}

Keywords: pluralism, Islamic education, multicultural

\begin{abstract}
ABSTRAK
Penelitian ini membahas tentang pendidikan toleransi melalui pembelajaran mata pelajaran Kema'arifan di SMA Ma'arif Bandung.Berbeda dengan penelitian yang lain, penelitian ini akan lebih membahas tentang suatu proses penanaman nilai toleransi di sekolah yang berlatar belakang organisasi Nabdatul Ulama (NU). Penelitian ini akan menguraikan bagaimana cara guru dalam menyampaikan nilai-nilai toleransi melalui suatu proses pembelajaran di kelas. Metode yang digunakan dalam penelitian ini adalah metode kualitatif dengan teknik pengumpulan data melalui wawancara, observasi, dan studi dokumen. Penelitian ini menunjukkan bahwa pembelajaran Kema'arifan mampu memberikan pengetabuan secara lebib mendalam tentang Islam, aswaja, serta golongan-golongan yang lainnya.Dalam proses pembelajaran, guru menyampaikan nilai-nilai toleransi melalui metode ceramah dan tanya jawab.
\end{abstract}

Kata kunci: pluralisme, pendidikan agama Islam, multikultural 


\section{PENDAHULUAN}

Pendidikan toleransi merupakan proses di mana guru mengajarkan siswa untuk menerima perbedaan. Tidak hanya sekedar menerima, namun siswa juga diajarkan untuk dapat menghormati berbagai macam perbedaan yang ada (Anwar, 2015, hal. 439). Berbicara mengenai perbedaan, Indonesia merupakan negara yang memiliki keanekaragaman latar belakang masyarakatnya.

Dapat dikatakan bahwa Indonesia merupakan negara yang masyarakatnya kaya akan perbedaan atau disebut sebagai masyarakat majemuk. Hal ini ditegaskan dengan adanya semboyan negara Indonesia yakni "Bhinneka Tunggal Ika". Sujanto (Lestari, 2005, hal. 35) menjelaskan, berdasarkan PP Nomor 6 Tahun 1951, ditetapkan bahwa: "Bhinneka Tunggal Ika" merupakan semboyan pada lembaga negara Republik Indonesia yang mengandung arti "walaupun berbeda-beda tetap satu". Melihat adanya semboyan tersebut maka seyogianya bangsa Indonesia memiliki ekspektasi tinggi terhadap persatuan bangsa walaupun terlahir di tengahtengah perbedaan masyarakat di dalamnya.

Salah satu keanekaragaman yang ada pada bangsa Indonesia adalah agama yang dianut oleh setiap warganya. Dalam perspektif sosiologis, menurut Joachim Wach (Jamrah, 2015, hal. 185), agama memiliki peran dan fungsi ganda, yakni konstruktif dan destruktif. Secara konstruktif, ikatan agama sering melebihi ikatan darah dan nasab atau keturunan. Sehingga karena agama, masyarakat dapat hidup rukun, bersatu, dan damai. Sebaliknya secara destruktif, agama memiliki potensi memporak-porandakan persatuan bahkan dapat memutus ikatan tali persaudaraan sedarah. Sehingga suatu konflik yang berlatarbelakang agama sulit untuk diprediksi kesudahannya.

Di Indonesia terdapat enam agama yang diakui di dalamnya yaitu Islam, Katholik, Protestan, Hindu, Budha, dan Konghucu. Adanya perbedaan dalam beragama semestinya tidak dijadikan alasan untuk mengurangi kerukunan dalam menjalani hidup berdampingan antar sesama manusia. Sebagaimana Yustiani (2008, hal. 71) menyatakan bahwa setiap agama mengajarkan kepada umatnya untuk saling mengasihi terhadap sesama makhluk hidup dan bersikap baik terhadap umat lain yang berbeda keyakinan atau agama.

Namun kenyataannya, Indonesia kerap mengalami konflik yang timbul akibat sentimen agama. Hasil penelitian The Wahid Institute pada tahun 2011 (Fidiyani, 2013, hal. 470) menyatakan bahwa:

Selama tahun 2011, telah terjadi peningkatan pelanggaran kebebasan beragama dan berkeyakinan di berbagai daerah di Indonesia. Apabila tahun sebelumnya hanya 64 kasus maka jumlah ini meningkat $18 \%$ menjadi 92 kasus. Bentuk pelanggaran kebebasan beragama yang paling tinggi adalah pelarangan atau pembatasan aktifitas keagamaan atau

TARBAWY: Indonesian Journal of Islamic Education - Vol. 5, No. 2 (2018) | 163 
Implementasi Pendidikan Toleransi di Sekolah: Sebuab Kearifan Lokal di Sekolah Nabdlatul Ulama

kegiatan ibadah kelompok tertentu dengan 49 kasus, atau 48\%, kemudian tindakan intimidasi dan ancaman kekerasan oleh aparat negara 20 kasus atau 20\%, pembiaran kekerasan 11 kasus (11\%), kekerasan dan pemaksaan keyakinan 9 kasus (9\%), penyegelan dan pelarangan rumah ibadah 9 kasus ( $9 \%$ ), dan kriminalisasi atau viktimisasi keyakinan 4 kasus (4\%).

Selain itu, Jayadi Damanik selaku Koordinator Desk Kebebasan Beragama dan Berkeyakinan Komnas HAM (Putro, 2017)menyebutkan bahwa jumlah pengaduan pelanggaran hak atas kebebasan beragama dan berkeyakinan kepada Komnas HAM mengalami peningkatan. Pada tahun 2014, terdapat sebanyak 74 pengaduan yang kemudian meningkat di tahun 2015 yakni sebanyak 87 pengaduan.

Kenyataan tersebut merupakan masalah yang sangat memprihatinkan, mengingat Indonesia merupakan negara yang menjunjung tinggi persatuan bangsa di tengah keanekaragaman latar belakang penduduknya. Ketika suatu perbedaan menjadi sebuah ancaman untuk kerukunan hidup, maka hal ini dapat menjadi masalah yang harus diselesaikan dengan sikap yang penuh toleransi (Lestari, 2005, hal. 32). Sikap toleransi sangat dibutuhkan untuk menghindari kasus-kasus serupa dan menciptakan kerukunan antar umat beragama. Hal ini sesuai dengan Peraturan Bersama Menteri Agama dan Mendagri Nomor 9 Tahun 2006 pasal 1 tentang Pedoman
Pelaksanaan Tugas Kepala Daerah /Wakil Kepala daerah dalam Pemeliharaan Kerukunan Umat Beragama, Pemberdayaan Forum Kerukunan Umat Beragama dan Pendirian Tempat lbadah (Mukhtaruddin, 2008, hal. 18) yang menyatakan bahwa:

Kerukunan umat beragama adalah keadaan hubungan sesama umat beragama yang dilandasi toleransi, saling pengertian, saling menghormati, menghargai kesetaraan dalam pengamalan ajaran agamanya dan kerjasama dalam kehidupan bermasyarakat, berbangsa dan bernegara di dalam negara kesatuan Republik Indonesia berdasarkan Pancasila dan Undang-Undang Dasar 1945.

Islam memberi pedoman bagi umatnya mengenai sikap toleransi khususnya kepada pemeluk-pemeluk agama lain. Piagam Madinah merupakan dokumen sejarah toleransi dan bukti adanya semangat kemanusiaan yang dilakukan oleh Rasulullah dalam menjalin kehidupan yang rukun (Ghufron, 2016, hal. 116).

Penanaman nilai-nilai toleransi dirasa sangat penting khususnya melalui proses pendidikan. Namun apabila pendidikan hanya menekankan pada transfer of knowledge, maka pendidikan dianggap kurang memberi makna efek positif bagi peserta didik. Pendidikan kurang menyentuh sisi humanisme yang pada akhirnya mengembangkan sikap pluralisme sebagai fondasi pemikiran multikulturalisme (Suyatno, 2013, hal. 81). Pendidikan seyogyanya juga 
menyentuh ranah transfer of value. Pendidikan nilai harus diposisikan sebagai target dari semua ikhtiar pendidikan sebab padahakikatnya tujuan pendidikan adalah pada tertanamnya nilai-nilai kehidupan yang baik dalamdiri peserta didik (Fakhruddin, 2014)

Padahal, melalui proses pendidikan, diharapkan para pendidik dapat menggunakan metode dan pendekatan yang tepat dalam memperkenalkan peserta didik dengan keragaman pemikiran agar dapat menghadapi dan memahami perbedaan yang ada (Ghufron, 2016, hal. 168).

Menurut UNESCO APNIEVE (Endang, hal. 105), langkah awal yang dilaksanakan dalam pendidikan toleransi ialah memperkenalkan peserta didik tentang hak-hak dan kebebasankebebasan bersama sehingga dapat saling menghormati dan diiringi dengan kemauan untuk melindungi hak-hak dan kebebasan orang lain.

Nahdatul Ulama (NU) merupakan organisasi Islam yang memiliki corak pemikiran yang khas, salah satunya mengenai toleransi. Organisasi ini lahir dari wawasan keagamaan dan wawasan kebangsaan (nasionalisme) (Setiawan, 2010, hal. 72-73). NU juga memiliki lembaga pendidikan yang disebut LP Ma'arif, dan di dalamnya terdapat pembelajaran yang menjadi ciri khas yang menjadi muatan lokal yaitu mata pelajaran Kema'arifan yang berisi tentang ke-NU-an dan paham Ahlu Al-Sunnab wa Al-jama'a (Aswaja). Pembelajaran
Aswaja NU mengatur hubungan antar manusia yang menuju kepada persaudaraan dan kerukunan berdasar sikap saling mengerti dan menghormati. Artinya, pembelajaran Aswaja NU bersifat plural, multikultural, toleran, tasamuh, tawazzun, dan sejenisnya (Fahmi, 2013, hal. 161-162).

Pendidikan toleransi memang lazim diterapkan di sekolah dan sudah banyak dilakukan penelitian. Peneliti melihat bahwa penelitian yang berkaitan dengan proses penanaman nilai-nilai toleransi di sekolah, pada umumnya dilakukan di melalui integrasi nilai karakter dalam setiap mata pelajaran, seperti pembelajaran PAI, PKn, dan lainlain. Namun peneliti masih jarang menemukan tentang pendidikan toleransi melalui pembelajaran Aswaja di sekolah berbasis NU.Adapun yang penelitian yang peneliti temukan ialah penelitian yang dilakukan oleh Muhammad Fahmi. Penelitiannya berjudul "Pendidikan Aswaja dalam Konteks Pluralisme”.

Penelitian yang dilakukan oleh M. Fahmi menunjukkan persamaan dengan penelitan yang dilakukan oleh peneliti, yakni mengkaji tentang nilai-nilai toleransi yang diajarkan dalam paham Aswaja. Aswaja NU mengajarkan tentang persaudaraan dan kerukunan hubungan antar manusia yang berdasar pada sikap saling mengerti dan menghormati. Namun terdapat pula perbedaan yang terlihat dari konteks antara kedua penelitian ini. Penelitian M.

TARBAWY: Indonesian Journal of Islamic Education - Vol. 5, No. 2 (2018) | 165 
Fahmi lebih menguraikan tentang konsep pendidikan Aswaja NU, sedangkan penelitian yang dilakukan oleh peneliti lebih mendeskripsikan bagaimana implementasi pembelajaran Aswaja yang dilakukan di sekolah NU yakni SMA Ma'arif Bandung serta bagaimana cara guru dalam menyampaikan nilainilaitoleransi yang diajarkan berdasarkan paham Aswaja.

Berkaitan dengan hal tersebut, dilakukanlah penelitian mengenai implementasi pembelajaran Aswaja di salah satu sekolah NU, yakni di SMA Ma'arif Bandung. Fokus dalam penelitian ini adalah memaparkan upaya guru dalam merancang pembelajaranserta nilai-nilai toleransi yang disampaikan guna mendidik siswa untuk menjadi pribadi yang toleran. Penelitian ini akan membahas tentang perencanaan, pelaksanaan, serta evaluasi pembelajaran mata pelajaran Kema'arifan.

\section{METODE PENELITIAN}

Penelitian ini dilakukan di SMA Ma'arif Bandung yang beralamat di Jalan Terusan Galunggung Nomor 9, Lingkar Selatan, Lengkong, Kota Bandung, Jawa Barat 40263, Indonesia. Alasan peneliti memilih lokasi ini dikarenakan SMA Ma'arif Bandung merupakan sekolah yang diasuh oleh Lembaga Pendidikan Ma'arif (LP Ma'arif) Nahdatul Ulama.

Dalam penelitian ini, peneliti menggunakan pendekatan kualitatif yang bersifat alami sesuai dengan situasi dan temuan di lapangan. Ali (2010, hal. 138) mengungkapkan bahwasanya penelitian kualitatif merupakan suatu pendekatan dengan melakukan riset yang berorientasi pada fenomena atau gejala yang bersifat alami.Berdasarkan uraian tersebut, maka penelitian ini akan mendeskripsikan secara fakta dan alami sesuai temuan di lapangan terkait implementasi pendidikan toleransi di SMA Ma'arif Bandung.

Adapun data dalam penelitian ini, diperoleh dan dikumpulkan melalui teknik wawancara, observasi, dan studi dokumen. Dalam melaksanakan wawancara, peneliti menjadikan guru mata pelajaran Kema'arifan sebagai narasumber utama dalam penelitian ini. Adapun pihak lain yang dijadikan peneliti sebagai narasumber yakni wakil kepala sekolah bidang kurikulum, guru mata pelajaran PAI, serta siswa-siswi SMA Ma'arif Bandung.

Observasi dilakukan guna mengamati proses pelaksanaan pembelajaran di kelas. Adapun yang peneliti amati dalam pelaksanaan pembelajaran yakni terkait langkah-langkah pembelajaran, penggunaan metode, media pembelajaran, materi ajar, serta nilai-nilai toleransi yang diajarkan. Kemudian untuk studi dokumen, peneliti mengumpulkan data berupa dokumendokumen terkait implementasi pembelajaran Kema'arifan.

TARBAWY: Indonesian Journal of Islamic Education - Vol. 5 No. 2 (2018) | 166 


\section{HASIL PENELITIAN DAN PEMBAHASAN}

\section{Perencanaan Pembelajaran}

Aswaja di SMA Ma'arif

Bandung

Pendidikan merupakan upaya yang paling efektif untuk mencegah tindakan intoleransi (Saulius, 2013, hal. 53). Sebab tindakan intoleran dapat memicu hal-hal negaitf yang berakibat pada kerusakan. Sikap intoleran dapat berupa penolakan terhadap sesuatu yang berbeda sehingga dapat berpotensi menimbulkan permusuhan dan ketakutan apabila menghadapi perbedaan (Khitruk \& Ulianova, 2012, hal. 31).

Pendidikan toleransi di SMA Ma'arif Bandung diterapkan melalui pembelajaran mata pelajaran Kema'arifan, yang mana pembelajaran ini juga dapat disebut pembelajaran Aswaja atau Ke-NU-an.

Tujuan dilaksanakannya pembelajaran Aswaja di SMA Ma'arif Bandung ialah untuk mengajarkan siswa tentang paham aswaja, yang mana salah satu konsep dari paham aswaja yakni lebih mengedepankan sikap moderat dan toleransi. Sebagaimana Masduqi (2011, hal. 135) menyatakan bahwa dalam pendidikan NU pada umumnya, toleransi merupakan ajaran yang sering disampaikan oleh para kyai maupun guru sehingga tertanam di hati para santri atau peserta didik. Adapun Aswaja merupakan golongan pengikut setia pada Ablu Al-Sunnał wa Al-Jama'ah, yaitu ajaran
Islam yang diajarkan dan diamalkan oleh Rasulullah Saw. bersama para sahabatnya pada zamannya (Fahmi, 2013, hal. 168).

Mukhtar dalam Fathurrohman (2012, hal. 36) menjelaskan bahwa terdapat ciri-ciri dasar yang mencerminkan ajaran Aswaja, ciri tersebut diantaranya pertama, tawasut, yakni sikap moderat baik dalam doktrin maupun sikap dan perilaku. Kedua, i'tidäl, yakni berkeadilan. Ketiga tasamuh, yakni toleran, tenggang rasa, tidak ekstrim, bersikap akomodatif, dan bisa menerima perbedaan pendapat. Ketiga, tawazzun, yakni harmoni, seimbang, tidak bersikap apriori menjaga kestabilan. Keempat, amar ma'rüf nabyì munkar, yakni menjalankan perintah-Nya dan menjauhi larangan-Nya.

Tasamuh atau toleransi menjadi salah satu ciri dari ajaran Aswaja. Berdasarkan hasil wawancara peneliti dengan narasumber, nilai-nilai toleransi yang hendak diberikan pada pembelajaran ini ialah sikap menghargai orang lain, karena sikap menghargai orang lain merupakan salah satu konsep toleransi yang penting untuk diterapkan agar manusia dapat bermasyarakat dengan baik. Sebagaimana konsep hidup dari Gus Dur yang dikenal dengan istilah pluralisme, yakni dapat menghargai orang lain, baik yang berbeda agama, suku, ras, dan apapun yang lainnya.

Perencanaan Aswaja di SMA Ma'arif Bandung masih dibuat dalam format kurikulum KTSP yang terdiri dari silabus dan RPP. Sedangkan silabus dan 
Implementasi Pendidikan Toleransi di Sekolah: Sebuah Kearifan Lokal di Sekolah Nahdlatul Ulama

RPP tersebut dibuat pada tahun 2015, dan belum ada pembaharuan kembali sampai saat ini.Sehingga dalam pelaksanaannya masih disesuaikan dengan situasi dan kondisi siswa dan sekolah, dan tidak mengacu pada perencanaan yang tertuang dalam bentuk silabus maupun RPP.

Melihat realitas tersebut maka dapat diasumsikan bahwa perencanaan pendidikan toleransi melalui pembelajaran mata pelajaran Kema'arifan masih terbilang kurang efektif dikarenakan belum adanya perencanaan matang yang dibuat khusus dan berkesinambungan. Menurut Ibrahim dan Syaodih (2003, hal. 51) program pembelajaran merupakan suatu program bagaimana mengajarkan apa-apa yang sudah dirumuskan dalam kurikulum. Maka yang menjadi acuan utama penyusunan program pembelajaran adalah kurikulum. Harjanto (2010, hal. 22) juga menjelaskan bahwa perencanaan pengajaran merupakan suatu alat yang membantu para pengelola pendidikan untuk lebih menjadi berdaya guna dalam melaksanakan tugas dan fungsinya. Kemudian apabila suatu perencanaan ingin menjadi alat yang berguna, maka perencanaan juga perlu didampingi dengan pengetahuan dan bekerja seseorang secara efektif.

Adapun cakupan materi dalam pembelajaran Awaja yakni meliputi konsep awal masuknya Islam serta perjuangan Islam di Indonesia, kemudian materi tentang Nahụatu Al-'Ulamā’, baik tentang sejarahnya, asal-usul, konsep berpikir dalam NU, kemudian ada juga tentang Islam rahmatan lil'alamin. Sebagaimana Wahid (2011, hal. 155) mengungkapkan bahwa pengkaitan NU terhadap proses perkembangan Islam di Indonesia meliputi beberapa aspek seperti keilmuagamaan yang dikembangkannya, pandangan kemasyarakatan yang dimilikinya, cara pengambilan keputusan umum yang digunakan, dan proses rekonsiliasi internal apabila terjadi perbedaan pandangan yang tajam. Adapun tradisi keilmuagamaan yang dianut NU yakni dikenal dengan sebutan akidah Ablu Al-Sunnat wa Al-Jama'a atau Aswaja.

\section{Pelaksanaan Pembelajaran Aswaja di SMA Ma'arif Bandung}

Pendidikan toleransi melalui pembelajaran Aswaja diterapkan pada siswa kelas X, XI, dan XII SMA Ma'arif Bandung dengan durasi selama 2x35 menit. Pada awal pembelajaran biasanya dimulai dengan berdoa bersama, mengecek kehadiran, lalu dilanjutkan dengan apersepsi. Doa yang dilakukan oleh guru dan siswa di kelas memiliki ciri khas tersendiri yang tidak pernah terlewatkan, karena mereka tidak hanya berdoa untuk diri sendiri, melainkan juga bertawasul kepada para ulama, kyai NU, guru, orang tua, serta saudara-saudara mereka.

Dalam pembelajaran Kema'arifan, siswa tidak hanya diajarkan tentang 
paham ke-NU-an, akan tetapi siswa juga akan diberikan pengetahuan tentang berbagai golongan-golongan dalam Islam serta perbedaan-perbedaan lainnya agar mereka dapat saling memahami dan menghargainya.Adapun pendekatan yang digunakan dalam pembelajaran yakni menggunakan pendekatan teacher center dengan metode ceramah dan tanya jawab. Sebagaimana Daradjat (2008, hal. 307) bahwa metode tanya jawab merupakan salah satu teknik mengajar yang mampu membantu menutupi kekurangan-kekurangan yang terdapat dalam metode ceramah. Metode tanya jawab juga dapat diterapkan oleh guru untuk menetapkan perkiraan secara umum apakah siswa sudah memahami bahan pelajaran yang telah disampaikan.Permbelajaran juga selalu diakhri dengan penyimpulan materi dan doa bersama.

Metode yang digunakan dalam pembelajaran Kema'arifan cukup menunjang proses pembelajaran di kelas. Hanya saja, peneliti melihat bahwa siswa juga perlu diperkenalkan dengan perbedaan secara nyata. Sebab pendidikan toleransi juga memerlukan adanya suatu interaksi antar golongan yang berbeda. Sebagaimana Saulius (2013, hal. 53) menytakan bahwasanya realisasi toleransi membutuhkan latar belakang yang beragam.Berdasarkan hasil riset yang dilakukan Firdaus \& Rahmat (2016, hal. 151) menunjukkan bahwa pembelajaran melalui penugasan dimana siswa diberi kesempatan untuk melakukan studi eksplorasi pemahaman dasar yang berbeda, dapat meningkatkan sikap toleran keagamaannya. Dalam hal ini, perbedaan yang dimaksud ialah perbedaan dalam keberagamaan. Misalnya, siswa di sekolah NU atau yang memiliki latar belakang NU, melalukan studi eksplorasi terhadap Muhammadiyah, PERSIS, atau agama-agama lain diluar Islam.

Adapun nilai-nilai toleransi yang diberikan pada proses pembelajaran di antaranya yakni: 1) sikap untuk saling menghargai dan menghormati perbedaan, 2) tidak menimbulkan konflik di tengah-tengah perbedaan, 3) mengutamakan amar ma'rüf nabyì munkar, 4) berdakwah dengan tidak memaksa dan tidak menimbulkan kerusakan, 5) tidak mudah memvonis perbedaan pada diri orang lain, 6) idak mudah marah dan mudah memaafkan, 7) tidak mudah memprovokasi maupun terprovokasi dengan hal-hal yang berakibat pada kerusakan. Hal ini sejalan dengan ungkapan Fahmi (2013, hal. 173-175), bahwasanya dakwah merupakan ajakan kepada masyarakat untuk menciptakan keadaan yang lebih baik, terutama menurut ajaran agama. Tidak mungkin orang berhasil mengajak seseorang dengan cara yang tidak mengenakkan hati yang diajak. Oleh sebab itu, berdakwah harus dilakukan dengan cara yang baik, bukan menghukum). Gus Dur seorang tokoh ulama NU juga mendalami arti perkataan Al-Syafi'i yang berbunyi, "Pendapat kami benar tetapi 
Implementasi Pendidikan Toleransi di Sekolah:

Sebuah Kearifan Lokal di Sekolah Nahdlatul Ulama

kemungkinan salah, sedangkan pendapat kalian salah tetapi mungkin benar", menunjukkan bahwa kebenaran pemikiran manusia tidaklah absolut dan seseorang tidak boleh merasa benar sendiri sembari menyesatkan pendapat orang lain. Gus Dur juga berpandangan bahwa perbedaan semestinya tidak menyebabkan perpecahan dan permusuhan. Menurutnya, perbedaan justru merupakan kasih sayang yang muncul di tengah-tengah kebhinekaan. Prinsip tersebut kemudian bersinergi dengan prinsip kebangsaan yakni Bhinneka Tunggal Ika. Sehingga menurutnya, toleransi berarti tidak mempersoalkan perbedaan agama, keyakinan, etnis, warna kulit, dan status sosial. Hal ini sejalan dengan salah satu firman-Nya dalam surat Al-Hujurat ayat 13 (Masduqi, 2011, hal. 135-136).

Shihab (2012, hal. 615-618) menafsirkan bahwa ayat tersebut menguraikan tentang prinsip dasar hubungan antar manusia. Semua manusia memiliki derajat kemanusiaan yang sama di sisi Allah, tidak ada perbedaan antara satu suku dan yang lainnya. Allah menciptakan perbedaan agar dapat saling mengenal. Perkenalan itu dibutuhkan untuk saling menarik pelajaran dan pengalaman guna meningkatkan ketakwaan kepada Allah yang dampaknya tercermin pada kedamaian dan kesejahteraan hidup di dunia dan akhirat. Tanpa saling mengenal, manusia tidak akan dapat menarik pelajaran, tidak dapat saling melengkapi serta tidak dapat saling menarik manfaat.

\section{Evalusai Pembelajaran Aswaja di SMA Ma'arif Bandung}

Berdasarkan hasil temuan di lapangan, evaluasi pembelajaran Aswaja dilakukan melalui evaluasi sumatif dan evaluasi formatif. Evaluasi sumatif dilakukan ketika pelaksanaan Ujian Akhir Semester (UAS), sedangkan evaluasi formatif dilakukan pada saat ulangan harian dan Ujian Tengah Semester (UTS). Adapun bentuk evaluasi yang digunakan yakni tes tertulis, dan tes lisan.Menurut Sanjaya (2015, hal. 239240), tes tertulis merupakan tes yang dilakukan dengan cara siswa menjawab sejumlah item soal dengan cara tertulis. Sedangkan tes lisan adalah bentuk tes yang menggunakan bahasa secara lisan.Tes lisan dianggap bagus untuk menilai kemampuan nalar siswa, sebab melalui tes ini, guru dapat mengetahui secara mendalam pemahaman siswa tentang sesuatu yang dievaluasi.

Adapun berdasarkan hasil wawancara peneliti terhadap guru mata pelajaran Kema'arifan dan Pendidikan Agama Islam (PAI), sikap toleransi sudah mulai tumbuh pada diri siswa dalam kesehariannya di kelas. Salah satu contohnya yakni ketika siswa melihat perbedaan pada diri temannya dalam hal pendapat maupun tata cara ibadah atau shalat. Ketika siswa dihadapkan pada realitas tersebut, mereka tetap bisa 
menghormati perbedaan pada diri temannya, tidak mengolok-olok, atau bahkan mengucilkannya.Selain itu, siswa juga mengakui bahwa setelah mengikuti pembelajaran Kema'arifan, mereka jadi lebih memahami dan menghargai perbedaan-perbedaan yang terdapat dalam Islam maupun di luar Islam. Hal ini selaras dengan teori yang dikemukakan oleh Turebayeva, dkk (2013, hal. 39-40) bahwa salah satu indikator toleransi ialah kesiapan untuk bekerja sama atau berinteraksi dalam berbagai situasi sosial. Toleransi dapat dilakukan dengan memahami dengan penuh hormat serta menerima keberagaman yang ada pada diri orang lain.

\section{KESIMPULAN}

Bersadasarkan hasil pembahasan yang telah diuraikan, maka peneliti menyimpulkan bahwa pembelajaran Kema'arifan di SMA Ma'arif memiliki tujuan untuk mengajarkan peserta didik tentang paham Aswaja. Paham Aswaja merupakan paham yang dianut dalam organisasi Nahdlatul Ulama, yang mana salah satu ciri dari paham tersebut yakni lebih mengedepankan sikap moderat dan toleran.

Pembelajaran ini mampu menanamkan nilai-nilai toleransi kepada siswa dengan memperkenalkan mereka terkait ragam perbedaan. Hal ini terlihat dari adanya perubahan sikap keseharian siswa. Hasil menunjukkan bahwa siswa sudah mampu menerima, memahami, serta menghargai perbedaan yang dihadapinya, baik di dalam maupun luar sekolah. Cakupan materi dalam bukubuku tersebut yakni meliputi konsep awal masuknya Islam serta perjuangan Islam di Indonesia, kemudian materi tentang Nahdatul Ulama, baik tentang sejarahnya, asal-usul, konsep berpikir dalam NU, kemudian ada juga tentang Islam rahmatan lil'alamin.

Di sini nampak jelas bahwa pembelajaran Aswaja juga memperlihatkan ciri kebangsaan. Proses penanaman nilai-nilai toleransi dalam pembelajaran Aswaja dilakukan dengan menggunakan metode ceramah dan tanya jawab. Artinya, disini guru tidak hanya menjelaskan di hadapan siswa, tetapi juga memancing siswa untuk bertanya, sekaligus berpikir dan berdiskusi bersama antara guru dengan siswa.

Adapun nilai-nilai toleransi yang diberikan pada proses pembelajaran di antaranya yakni: 1) sikap untuk saling menghargai dan menghormati perbedaan, 2) tidak menimbulkan konflik di tengah-tengah perbedaan, 3) mengutamakan amar ma'rüf nabyi munkar, 4) berdakwah dengan tidak memaksa dan tidak menimbulkan kerusakan, 5) tidak mudah memvonis perbedaan pada diri orang lain, 6) tidak mudah marah dan mudah memaafkan, 7) tidak mudah memprovokasi maupun terprovokasi dengan hal-hal yang berakibat pada kerusakan. 
Implementasi Pendidikan Toleransi di Sekolab: Sebuab Kearifan Lokal di Sekolah Nabdlatul Ulama

Indonesia

(Belajar

\section{REFERENSI}

Ali, M. (2010). Metodologi dan Aplikasi Riset Pendidikan. Bandung: Pustaka Cendekia Utama.

Anwar, S. (2015). Tolerance Education Through Islamic Religious Education in Indonesia. The 1st UPI International Conference on Sociology Education (UPI ICSE 2015) (pp. 438-442). Bandung: Atlantic Press.

Daradjat, Z. (2008). Metodik Khusus Pengajaran Agama Islam. Jakarta: PT. Bumi Aksara.

Endang, B. (n.d.). Mengembangkan Sikap Toleransi dan Kebersamaan di Kalangan Siswa. Jurnal Visi Ilmu Pendidikan, 89105.

Fahmi, M. (2013, Mei). Pendidikan Aswaja NU dalam Konteks Pluralisme. Jurnal Pendidikan Agama Islam, 01 Nomor 01, 161179.

Fakhruddin, A. (2014). Urgensi Pendidikan Nilai Untuk Memecahkan Problematika Nilai dalam Konteks Pendidikan Persekolahan. Jurnal Pendidikan Agama Islam -Ta'lim, 12(1), 79.

Fathurrohman. (2012, Juni). Aswaja NU dan Toleransi Umat Beragama. Jurnal Review Politik, 02 Nomor 01, 34-45.

Fidiyani, R. (2013, September). Kerukunan Umat Beragama di
Keharomonisan dan Toleransi Umat Beragama Di Desa Cikakak, Kec. Wangon, Kab. Banyumas). Jurnal Dinamika Hukum, 468-482.

Firdaus, E., \& Rahmat, M. (2016). Learning Model of Religious Tolerance (A Study of the Increase of Life Cohesion for Students). Islamic Education Faces Global Challenges, 151-155.

Ghufron, F. (2016). Ekspresi Keberagamaan di Era Milenium. Yogyakarta: IRCiSoD.

Harjanto. (2010). Perencanaan Pengajaran. Jakarta: Rineka Cipta.

Ibrahim, R., \& Syaodih, N. (2003). Perencanaan Pengajaran. Jakarta: PT. Rineka Cipta.

Jamrah, S. A. (2015, Juli). Toleransi Antar Umat Beragama : Perspektif Islam. Jurnal Ushuluddin, 23, 155-200.

Khitruk, V. V., \& Ulianova, O. A. (2012). Inclusive Tolerance as a Basis of Professional Competence of Prospective Teachers. Problems of Education In The 21st Century, 43, 21-33.

Lestari, G. (2005, Februari). Bhinneka Tunggal Ika: Khasanah Multikultural Indonesia di Tengah Kehidupan Sara. Jurnal Pendidikan Pancasila dan Kewarganegaraan, 31-37.

Masduqi, I. (2011). Berislam Secara Toleran. (I. D. S., Ed.) Bandung: Mizan. 
Mukhtaruddin. (2008, April). Pembinaan

Kerukunan Umat Beragama

Masyarakat Transmigran di

Kalimantan Tengah. Analisa,

XV, 15-32.

Putro, G. A. (2017, Januari 05).

DetikNews. Retrieved Februari

08, 2017, from detik.com:

https://news.detik.com/berita/d

-3388574/mabes-polri-ungkap-4-

faktor-pemicu-konflik-intoleransi

Sanjaya, W. (2015). Perencanaan dan Desain

Sistem Pembelajaran. Jakarta:

Prenadamedia Group.

Saulius, T. (2013). What is "Tolerance"

and "Tolerance Education"?

Philosophical Perspectives.

Socialiniai Mokslai, 49-56.

Setiawan, Z. (2010, Januari). Pemikiran dan Kebijakan Nahdlatul Ulama dalam Menjaga Kedaulatan Wilayah Negara Kesatuan

Republik Indonesia pada Era Reformasi (1998-2009). Jurnal Ilmu Politik Hubungan Internasional, 7 No. 1, 72-85.

Shihab, M. Q. (2012). Tafsir Al-Misbah.

Tangerang: Lentera Hati.

Suyatno.

(2013,

Februari)

Multikurlturalisme Dalam

Pendidikan Agama Islam:

Problematika Pendidikan Agama

Islam di Sekolah. Addin, 7(1), 81-

104.

Turebayeva, C. Z., Doszhanova, S. Y., Orazova, Z. O., \& Zhubatyrova, B. T. (2013). Education of Tolerant Personality of a Future
Specialist. Middle-East Journal of Scientific Research 13 (SocioEconomic Sciences and Humanities), $38-42$.

Wahid, A. (2011). Prisma Pemikiran Gus Dur. (M. S. Isre, Ed.) Yogyakarta: LKiS Group.

Yustiani. (2008, Mei). Kerukunan Antar Umat Beragama Kristen dan Islam di Soe, Nusa Tenggara Timur. 54.Nalisd, XV, 71-84. 